\title{
Corporate Governance and Firm Efficiency: Evidence from China's Publicly Listed Firms*
}

\author{
Chen $\operatorname{Lin}^{\mathrm{a} * *}$, Yue $\mathrm{Ma}^{\mathrm{a}, \mathrm{b}}$, Dongwei Su ${ }^{\mathrm{c}, \mathrm{d} \text {, }}$ \\ ${ }^{a}$ Department of Economics, Lingnan University, Hong Kong \\ ${ }^{\mathrm{b}}$ Macroeconomic Research Center, Xiamen University, China \\ ${ }^{\mathrm{c}}$ Department of Finance, Jinan University, Guangzhou 510632, China \\ ${ }^{\mathrm{d}}$ Research Institute of Finance, Jinan University, Guangzhou 510632, China
}

\begin{abstract}
This paper applies a two-stage, double bootstrapping data envelope analysis (DEA) approach to investigate whether and to what extent various distinctive corporate governance practices affect productive efficiency in a sample of 461 publicly listed manufacturing firms in China between 1999 and 2002. We find that firm efficiency is negatively related to state ownership while positively related to public and employee share ownership. The relationship between ownership concentration and firm efficiency is U-shaped, indicating the presence of tunneling activities by the largest shareholder. Among three types of controlling shareholder, state exerts the most negative impact on firm efficiency, followed by state-owned legal entities. These results provide strong evidence that political interferences have reduced firm efficiency. In addition, we find that the proportion of outside directors and the number of board meetings are positively associated with firm efficiency, suggesting that board of directors can be an effective internal governance mechanism. Furthermore, we find that provincial market development, a proxy for the strength of external governance mechanism, is positively related to firm efficiency. Overall, our findings illustrate that restructuring state-owned enterprises via improvements in corporate governance has enhanced firm efficiency, but partial privatization without transfer of ownership and control from the state to the public remains a major source of inefficiency in corporate China.
\end{abstract}

Keywords: Corporate governance, Efficiency, Data envelopment analysis, China JEL classification: D24; G30; P31

\footnotetext{
* We thank two anonymous referees, Sanford Berg, Joel Houston, Guohua Jiang, Alan Stent, Lihui Tian, Tracy Wang, and participants at the fifth annual China Economic Conference, the Sixth Annual International Conference on Financial Engineering, and the Journal of Banking and Finance $30^{\text {th }}$ Anniversary International Conference for their helpful comments and suggestions. The financial support from Lingnan University (DR07B2) and the RGC of Hong Kong SAR Government (No. LU3110/03H) is gratefully acknowledged. Su also wishes to acknowledge the financial support from the National Natural Science Foundation of China (Grant No. 70572065), the Ministry of Education of China (Grant No. 200403), the Guangdong Project of Key Research Institute of Humanities and Social Sciences at Universities (Grant No. 04JDXM79001 and 07JDTDXM79005) and the Innovative Research Team Project of Jinan University (Grant No. 04SK2D03). However, we are responsible for all remaining errors of this paper.

${ }^{* *}$ Corresponding author. Tel.: (852)26167200; fax: (852)28917940.

E-mail address: chen.lin@1n.edu.hk
} 


\section{Introduction}

Corporate governance is a set of mechanisms, both institutional and market based, designed to mitigate agency problems that arise from the separation of ownership and control in a company, protect the interests of all stakeholders, improve firm performance, and ensure that investors get an adequate return on their investment (Shleifer and Vishny, 1997; La Porta et al, 2000). Governance mechanisms can be classified into internal monitoring mechanisms including ownership structure, board characteristics, outside supervision and executive compensation, and external monitoring mechanisms such as legal system, active takeover market and production market competition (Huson et al., 2001; Denis and McConnell, 2003).The effectiveness of corporate governance mechanisms has been a subject of academic research for many decades. Although the large majority of corporate governance studies prior to mid 1990s were based on data from developed market economies such as the U.S., U.K. and Japan, in recent years researchers began looking into corporate governance in transition economies (Dnes, 2005) ${ }^{1}$. This endeavor is partly motivated by the world-wide surge of enterprise privatization and market liberalization as governments of all ideological stripes initiated various institutional reforms to decentralize and commercialize their state-owned enterprises (SOEs), and in some cases, to massively transfer ownership and control of SOEs to the public (Megginson and Netter, 2001). For example, Djankov and Murrell (2002) document that more than 150,000 large SOEs in transition economies have undergone enterprise restructuring and experienced revolutionary changes in political and economic environments in 1990s, which provides a fertile ground for analyzing age-old issues such as the relative productivities of state versus private enterprises and the cost efficiency of diffuse share ownership relative to large shareholder control. Estrin (2002) argues that transition economies make a particularly good laboratory for understanding the evolution of corporate governance structure and for evaluating the impact of alternative governance mechanisms and policy frameworks. While researchers have broadened their use of governance data to include privatized former SOEs in their studies, research into the

${ }^{1}$ Dennis and McConnell (2003) provide a good survey of the literature on international corporate governance. 
effectiveness of corporate governance in transition economies remains limited. The objective of this paper is to expand the literature on the corporate governance of transition economies by disentangling the effects of corporate governance mechanisms on firm efficiency in China, the largest transition economy in the world.

In recent years, there has been a growing interest in corporate governance in China (Liu, 2005). Qian (1996) shows that China shares many of the typical institutional characteristics as a transition economy, including poor legal protection of creditors and investors, the absence of an effective takeover market, an underdeveloped capital market, a relatively inefficient banking system and significant interference of politicians in firm management. Sun and Tong (2003) show that share issuance privatization (SIP) has improved earnings, sales and workers' productivity, but has not increased returns to investors. They also show that state ownership is associated with poor SOE performance and that legal entity ownership is tied to better firm performance. Wei et al. (2005) present evidence that Tobin's $q$ is negatively related to state and institutional shares but positively related to foreign ownership for a sample of privatized former SOEs during 1991 and 2001. Allen et al. (2005) demonstrate that standard corporate governance mechanisms are weak and ineffective for publicly listed firms while alternative governance mechanisms based on reputation and relationship have been remarkably effective in the private sector. Aivazian et al. (2005) provide evidence that CEO turnover is tightly linked to firm performance, suggesting that enterprise restructuring has improved corporate governance in China. However, However, Firth et al. (2006b) find no evidence that firm performance improves following the turnover of the board chairman, suggesting that internal governance structure may not be effective among China's listed firms In another study, Firth et al. (2006a) find that CEO pay-performance sensitivity is significantly positive for all publicly listed firms but statistically insignificant for state controlled firms, suggesting that government weakens corporate governance and pay-performance incentives for CEOs. The reason that China draws so much attention is because China offers a unique environment for analyzing corporate governance and firm performance. First, China's SOE reform strategy hinges on the Modern Enterprise System characterized by the separation of ownership and control (Su, 2005). Ownership of an SOE's assets is distributed 
among the government, institutional investors, managers, employees, and private investors. Effective control rights are assigned to management, which generally has a very small, or even nonexistent ownership stake. This distinctive shareholding structure creates conflict of interest not only between management (insiders) and outside investors but also between large shareholders and minority investors. Moreover, because Chinese government desires to retain some control - in part through partial retained ownership of commercialized SOEs, further conflicts arise between politicians and firms (Shleifer and Vishny, 1994). Therefore, it is of interest to assess whether and to what extent this complex ownership structure affects firm performance and efficiency in China's corporations. Second, board of directors in publicly listed firms consists mainly of representatives or officials from the government and other state enterprises, whose interests may not be in line with those of outside investors. Board members no doubt care more about carrying out the wishes of the government, such as avoiding worker layoffs and maintaining some level of worker social security than about the concerns of shareholders. As a result, internal governance mechanisms, such as the number of outside directors on the board and the number of outside supervisors on the supervisory committee, may influence firm performance and efficiency. Third, because of the political nature of the privatization process itself, typical external governance mechanisms, such as debt (in conjunction with appropriate bankruptcy procedures), takeover threats, legal protection of investors, product market competition, etc., have not been effective (Su, 2005). Bank loans have traditionally been viewed as grants from the state designed to bail out failing firms. State-owned banks retain a monopoly in the banking sector and profit is not their overriding objective. If political favor is deemed appropriate, subsidized loans, rescheduling of overdue debt or even outright transfer of funds can be arranged with SOEs (soft budget constraints). In addition, a market for private, non-bank debt has yet to be established. There is no active merger or takeover activity in stock markets to discipline management. Information available in the capital markets is insufficient to keep at arm's length of the corporate decisions. In light of these peculiarities, a proxy for the strength of provincial market liberalization, economic freedom and legal environment may help explain the cross-sectional variation in firm performance and efficiency. Fourth, several social 
reforms (corporatization, privatization and marketization) are ongoing in China. These social experiments enable us to find out the most important efficiency driving factors and contribute to the debate about whether privatization is necessary in improving firm performance (Aivazian et al., 2005).

In this paper, we investigate whether and to what extent the aforementioned distinctive characteristics of governance mechanisms affect productive efficiency in a sample of 461 publicly listed manufacturing firms in China between 1999 and 2002. ${ }^{2}$ A clear distinction between our paper and the existing literature is that we simultaneously consider a number of unique corporate governance practices (e.g., complex ownership structure, controlling shareholder identities, and outside directors and supervisors) inherent in the reform of SOEs in China and include a proxy for the strength of provincial market liberalization and legal environment to account for the effects of external governance mechanisms on firm performance. As Boubakri et al., (2005) point out, the ultimate success of privatization depends on the effectiveness of post-privatization corporate governance mechanisms. Most of the existing studies omit some aspects of governance practices, which may induce endogeneity problems in regression analyses (Megginson and Netter, 2001; Denis and McConnell, 2003). Moreover, privatizations are often accompanied by massive economy-wide changes such as reduction in government intervention, deregulation of price control, development of product markets and improvement of legal environment, but the literature usually fails to incorporate these changes into the empirical models to isolate the impacts of market liberalizations on firm performance. ${ }^{3}$ Therefore, our paper contributes to the literature on corporate governance of transition economies

${ }^{2}$ Efficient frontier methodologies usually summarize firm performance in a single statistic that controls for differences among firms using a sophisticated multidimensional framework. The statistic can be used in a variety of ways to assist managers to evaluate relative firm performance in terms of technology, scale, cost minimization and revenue maximization. Chinese stock markets are often plagued with speculative activities and earnings management. Thus, measures of productive efficiency (estimated via DEA) are superior to accounting-based performance measures.

${ }^{3}$ As the degree of marketization (adoption of market-based policies) increases, SOEs will be exposed to more intense competition and managers will more likely be held accountable for poor firm performance, leading to more effective corporate governance practices. Megginson and Netter (2001) assert that "privatization tends to have the greatest positive impact in cases where the role for government in lessening market failure is the weakest". Hence, the degree of marketization can be an important factor in determining firm performance. 
by providing a more comprehensive test of the relationship between corporate governance mechanisms and firm efficiency in the context of China. By doing so, our study complements the study of Liu (2005), which provides a qualitative introduction to corporate governance in China. In addition, our study contributes to the ongoing debate on whether ownership change (privatization) is necessary for improving the efficiency of SOEs ${ }^{4}$.

In Section 2, we quantify measures for internal versus external governance mechanisms and outline testable hypotheses on the relationship between corporate governance variables and firm efficiency. In Section 3, we describe the data and characterize the distribution of firm observations across time and sub-industries, and present summary statistics. In Section 4, we discuss the DEA methodology for calculating firm efficiency scores and present empirical results from second-stage regressions with efficiency score as dependent variable and governance proxies as independent variables. In the last section, we conclude the paper and draw policy implications from our results.

\section{Corporate governance variables and hypotheses}

In this section, we discuss measures of internal versus external governance mechanisms and outline testable hypotheses on the relationship between corporate governance variables and firm efficiency.

\subsection{Ownership structure}

The ownership structure of China's listed firms can be classified into four main categories: state shares (STATE), legal entity shares (LEGAL), publicly tradable shares (PUBLIC) and employee shares (EMPLOYEE). ${ }^{5}$ State shares are retained by the State Assets Management

${ }^{4}$ Boycko et al. (1996), Shleifer (1998) and Shirley and Patrick (2000) assert that because governments cannot play an active role in corporate governance, ownership change is necessary for any significant performance improvements of SOEs. On the other hand, Vickers and Yarrow (1991), Allen and Gale (2000) and Aivazian et al. (2005) argue that less radical methods such as managerial incentive contracts, market deregulation, and internal and external governance reform can be effective substitutes to outright privatization.

5 The official shareholding classification of state and legal entity is somewhat misleading, in that the government can extend its ownership and control of an SOE through pyramidal shareholding scheme. Liu and Sun (2003) find that $84 \%$ of the listed companies in their sample are ultimately controlled by the state. We find that $86 \%$ (1571 out of 1817) of the firms in our sample are ultimately owned by the state. 
Bureau (SAMB) of the central or local government and are not allowed to be publicly traded, although reforms have been initiated to free up these shares since May $2005 .^{6}$ For the reasons outlined below, we hypothesize that STATE is negatively related to firm efficiency. First, while in theory publicly listed former SOEs are owned by all investors, they are actually controlled by bureaucrats who have extremely concentrated control right but no significant cash flow right since the latter is dispersed amongst the taxpayers of the country (Shleifer and Vishny, 1997). The bureaucrats' main concern is to achieve their political and economic interests, which are often quite different from shareholders' profit maximization objective (Shleifer and Vishny, 1994; Boycko et al., 1996). Second, SOE managers have weak or sometimes adverse incentives to improve firm efficiency, because "as public employees, SOE managers cannot personally reap the benefits of increasing revenues yet they will bear many of the costs (e.g., angry workers and disgruntled suppliers) of reducing the firm's production costs" (Megginson, 2005). Third, soft budget constraint is regarded as another major source of inefficiency of state ownership (Kornai, 1986; Lin et al., 1998). When government can indirectly subsidize SOEs to maintain bloated employment levels, employee housing, schooling and other political objectives through control over transfers from the treasury, thus creating a soft budget constraint, SOEs cannot be effectively disciplined by the working of the capital market.

Legal entity shares are held by domestic institutional investors including securities and insurance companies, mutual funds and industrial enterprises. Similar to state shares, legal entity shares are not tradable and most of them are ultimately controlled by the state through its control over legal entities. However, as pointed out by Sun and Tong (2003), there exist

${ }^{6}$ On average, the state retains about one third of the shares outstanding and is the largest shareholder in more than $40 \%$ of the listed firms. This phenomenon is quite similar to that in other transition economies. According to Estrin (2002), the state retained a fraction of shares in one out of every four privatized firms in 20 of the 23 transition economies. However, beginning in May 2005, shares of a majority of publicly listed firms in China have moved from "partially tradable" to "fully tradable", or have become the so-called "G shares". During this process, the holders of non-tradable shares have agreed to provide the holders of tradable shares with free shares, cash, warrants or some other means of compensation in exchange for their shares to become tradable. By the end of 2006, 1,139 listed firms representing $84 \%$ of the market capitalization have completed the share reform. However, non-tradable shares are subject to a lock-up period and have not yet become tradable. Specifically, according to the CSRC's guidelines, only up to $5 \%$ of the non-tradable shares can be floated one year after the completion of the reform; another 5\% can be traded in the second year following the reform and the remaining non-tradable share can become tradable only after three years following the reform. 
important differences between outright state ownership and legal entity share ownership, which lead to different implications for corporate governance. In particular, because many legal entities have close business connections with the listed firms in which they have ownership, they have incentives to be active in corporate governance. Compared with government officials or individual shareholders, legal entity shareholders have more expert knowledge of the firm and are better equipped with the power to monitor managers through their influence on the board of directors. However, it is also quite possible that legal entity shareholders may expropriate assets or cash flows from the listed firms. As a result, the impact of legal entity share ownership on firm efficiency is an interesting empirical question to be addressed in this paper.

Public shares are held by private investors and tradable on the two securities exchanges. Although it is reasonable to believe that as the proportion of the public ownership increases, private investors will have more power to elect their representatives to the board and monitor managerial performance, unfortunately their power is limited by the fact that public shares are dispersed among millions of individual investors and the Company Law does not contain clear provisions on the protection of minority shareholders. Therefore, the relationship between public share ownership and firm efficiency is also an empirical question to be further explored.

Employee shares are offered to workers and managers of a listed firm, typically at substantial discounts, at the time of initial public offerings (IPOs). ${ }^{7}$ Employee stock ownership has the potential to mitigate the agency problem between insiders and outside investors and provide insiders with incentives for better performance, which may create a positive impact on the productivity of employees. Therefore, we hypothesize that EMPLOYEE is positively related to firm efficiency. ${ }^{8}$

${ }^{7}$ With the approval from the China Securities Regulatory Commission (CSRC), employee shares can become tradable after a lockup period of 6 to 12 months. A number of companies have established shareholding association or labor union to buy back shares in case that an employee retires, resigns, gets fired or dies. In such cases, employee shares are generally priced on the basis of their net asset value. In 1998, the CSRC issued a circular to cease the issuance of employee shares. As a result, the number of employee shares has gradually declined. On November 12, 2005, the CSRC issued a tentative circular to encourage the use of stock ownership and stock options as alternative forms of incentive compensation for managers.

${ }^{8}$ Himmelberg et al. (1999) argue that insider ownership and firm performance may be jointly determined and that variation in insider ownership is endogenous. Endogeneity is not a problem in our sample, because employee share ownership is not used as incentive compensation and does not vary with firm 


\subsection{Ownership concentration}

Consistent with existing literature, we measure ownership concentration as the percentage of shares held by the largest shareholder (LARGEST). In theory, a controlling shareholder can affect minority shareholders' rights and firm performance in two opposite ways. Shleifer and Vishny (1997) argue that ownership concentration is, along with legal protection, one of two key determinants of corporate governance. Large shareholders can benefit minority shareholders because they have the power and incentive to prevent expropriation or asset stripping by managers. In this vein, ownership concentration can be viewed as an efficient governance mechanism. On the other hand, large shareholders can collude with managers to expropriate minority shareholders' benefits, which is called "tunneling" (Johnson et al., 2000) and described as one of the central agency problems in countries with relatively poor shareholder protection (La Porta et al., 1999; 2000). Morck et al. (2000) also discuss how controlling shareholders may pursue objectives that are at odds with those of minority shareholders. Therefore, the relationship between ownership concentration and firm efficiency is a complex empirical question. When ownership of shares is widely dispersed, increasing ownership concentration is likely to mitigate the free-rider problem and enhance firm efficiency. However, when the fractional ownership of the largest shareholder exceeds a certain threshold, increasing ownership concentration raises the likelihood of tunneling and decreases firm efficiency. As ownership concentration approaches $100 \%$, the tunneling effect diminishes and the relationship between ownership concentration and firm efficiency becomes positive again. In light of the institutional background in China, i.e., there is usually one overwhelmingly large shareholder with controlling power in the listed firms, we hypothesize that the last two effects dominate in the data and the relationship between ownership concentration and firm efficiency is U-shaped.

Because different types of controlling shareholder may have different incentives to engage in monitoring versus tunneling activities, we introduce two dummy variables (STATECTRL and LEGALSTACTRL) to capture the effects of the identity of controlling shareholders on firm efficiency. As Chen, Firth and Rui (2006) point out, the ownership types used by previous studies

performance. 
(e.g., Sun and Tong 2003, Wei et al. 2005) are very simplistic and may lead to erroneous conclusions. They argue that it is far better to define ownership in terms of the dominant shareholder's objectives than using the legal categorization of state and legal entity shares. Specifically, they classify the state and legal entity investors into bureaucratic agencies (State Asset Management Bureau) and those that are SOEs (even though some of the SOEs may hold state shares and some may own legal entity shares). In the spirit of their classification, we create two dummy variables which capture the identity of the firm's controlling shareholder. STATECTRL takes the value 1 if the government (via the State Asset Management Bureau) is the controlling shareholder and 0 otherwise. LEGALSTACTRL takes the value 1 if the state-owned legal entity (state owned enterprise) is the controlling shareholder and 0 otherwise. Hence, the benchmark group comprises of firms with non state-owned legal entities as controlling shareholders. For reasons discussed in Section 3.1, we hypothesize that STATECTRL has the greatest negative impact on firm efficiency, while the effect of LEGALSTACTRL is an empirical question. Moreover, because government can extend its ownership and control through pyramidal shareholding scheme, we introduce a separate dummy variable ULTIMATE to examine the effect of the identity of ultimate owners on firm efficiency. ULTIMATE takes the value 1 if the government is the ultimate owner and 0 otherwise. We hypothesize that ULTIMATE is negatively related to firm efficiency. ${ }^{9}$

\subsection{Board characteristics}

We use the following three variables to characterize the board of directors. The first variable is the ratio of outside directors in the board of directors (OUTDRATIO). The outside directors are defined as directors who are not members of the management team. ${ }^{10}$ Fama and

${ }^{9}$ We obtain data on the identity of the controlling shareholder and ultimate owner from the CCER-SinoFin database developed by Peking University. We then classify the identity of controlling shareholders into STATECTRL, LEGALSTACTRL and others. We find that $86 \%$ of the firms in our sample are ultimately owned by the state.

10 According to the guideline established by the CSRC, an independent director must meet the following requirements: (i) neither the individual nor his relatives works for the listed firm or its subsidiaries; (ii) the individual does not directly or indirectly own more than $1 \%$ of the stock of the listed firm; (c) neither the individual nor his close relatives (including parents, spouses and children) works for one of the five largest shareholders or a company that owns more than $5 \%$ of the shares of the listed firm. As a result, most of the independent directors are drawn from government departments, research institutions and universities. During our sample period (1999-2002), firms are required to have 
Jensen (1983) argue that outside directors generally care about their reputations and social status, thus have incentives to monitor the management and ensure the effective running of the company. Hence, we hypothesize that OUTDRATIO is positively related to firm efficiency. The second variable is manager/CEO duality (DUALITY), which equals to 1 if general manager/CEO is also the board chair and 0 otherwise. Dalton and Kesner (1997) argue that holding the board chair position enables the CEO to exert more impact on corporate agenda and decisions, which makes the governance function of the board weaker. Therefore, we hypothesize that DUALITY is negatively related to firm efficiency. Furthermore, we use the number of board meetings per year (BOARDMEETING) as a proxy for board activeness and hypothesize that BOARDMEETING is positively related to firm efficiency.

\subsection{The structure of the supervisory committee}

According to the Company Law, each publicly listed firm in China must establish a supervisory committee consisting of representatives of shareholders and employees in appropriate proportions. The duties of the supervisors are to scrutinize decisions made by managers, directors and other senior personnel, to review and audit reports provided by directors, to safeguard the firm's assets, and to resolve disputes arisen between shareholders and directors. In practice, the supervisory committee is headed by the Communist Party leaders of the firm and does not have finance and audit sub-committees. More importantly, it is only equipped with the right of supervision, without the right to select managers and directors and to veto the decision of the board or management. Hence, the supervisory committee is more decorative than functional. We use the ratio of outside supervisors (OUTSUPERRATIO) to characterize supervisory committee structure, and hypothesize that this variable has very limited positive impact on firm efficiency.

\subsection{Marketization index}

One special feature of China is its imbalanced regional development caused by factors including geographic conditions, human capital accumulation, infrastructure investment, industry

non-executive directors on the board. However, it was not until June 2003 that non-executive directors are required to be "independent" (Chen, Firth, Gao and Rui, 2006). Therefore, non-executive directors in our analysis are similar to outside directors, who may be representatives of all major stockholders. 
agglomeration, trade and FDI openness, and local market liberalization policies. Therefore, we introduce a set of provincial dummies to control for regional-specific effect on firm efficiency. In addition, we use the NERI (National Economic Research Institute of China) provincial marketization index (MARKETIZATION) complied by Fan and Wang (2004) to proxy for the strength of external corporate governance mechanism and differences in regional market development. The marketization index characterizes the progress of the transition towards the market economy in areas including the extent of government intervention, the degree of market competition, the development of product and factor markets and the strength of legal environment, for 31 provinces and special administrative regions. ${ }^{11}$ A higher index value indicates less government intervention and more regional economic freedom. Therefore, we hypothesize that the relationship between marketization index and firm efficiency is positive.

\subsection{Firm size}

The economy-of-scale of a firm is captured by the firm size. We employ the log of

${ }^{11}$ Specifically, the NERI marketization index is constructed based on the following indicators of a well-functioning market system: (i) The relationship between provincial government and markets, including the size of the provincial government (fiscal revenue as a percentage of provincial GDP); the financial burden of firms besides normal taxes (proxied by the public financial burden on farmers); and the level of government control and efficiency (derived from a survey of business executives on the amount of time allocated to deal with the government bureaucracies). (ii) Development of non-state sectors, including the ratio of private sector employees and total labor force and the ratio of private sector and total industrial outputs. (iii) Development of product markets, including the extent of price deregulation (percentage of products with prices allowed to be determined by the market) and the size of inter-regional trade barrier (derived from a survey of business executives regarding restrictions against the sales of their products). (iv) Development of factor markets, including competition in the banking sector (the total assets of non-state banks as a percentage of total assets in the entire banking sector); improvement in investment policies and environment (FDI as a percentage of total investment); and labor mobility (the ratio of immigrated laborers and labor force adjusted for regional income differences). (v) Development of legal framework for property protection and contract enforcement, including the development of legal institutions (the number of law firms, accounting offices and independent auditing offices adjusted for differences in population); market order (the number of cases of trademark violations); property right protection (the number of patent applications and actual registrations); and consumer protection (the number of legal cases of consumer complaints). For each of the above indicators, Fan and Wang (2004) assign a value between 0 and 10, with higher values being indicative of higher degree of marketization and economic freedom, and determine the weight for each indicator using principal component analysis. 
fixed-asset of the firm (LOGASSET) as a proxy for the firm size. If there is an economy-of-scale, the coefficient of the LOGASSET should be positively significant, indicating that larger firms should be expected to be more efficient.

\section{Data and summary statistics}

The sample used in this study consists of 461 firms listed on the Shanghai and Shenzhen securities exchanges. ${ }^{12}$ Most of the sample firms are partially privatized former SOEs. The corporate governance variables discussed in Section 2 are constructed from the annual and semi-annual financial reports between 1999 and 2002. The final sample is an unbalanced panel consisting of 1648 firm-year observations. All data are from the Chinese Stock Market and Accounting Research (CSMAR) database, constructed by the University of Hong Kong and Shenzhen GTA Company according to the format of CRSP and COMPUSTAT.

Based on the classification criteria issued by the CSRC, we divide the sample manufacturing firms into 9 single-digit and 33 double-digit sub-industries. Tables 1 and 2 characterize the distribution of observations and present summary statistics of the output and inputs of the firms as well as their corporate governance variables. As shown in table 2, sub-industry 6 (metal, mineral and cement) is the largest manufacturing industry on average in terms of revenues (REVENUE), number of employees (EMPLOYEE), capital stock (KSTOCK), and intermediate inputs (INTERM). The ownership structure does not vary much across sub-industries. On average, sub-industry 3 (paper and allied products) has the highest (43\%) state ownership and lowest $(16.8 \%)$ legal entity ownership while sub-industry 9 (other manufacturing) has the lowest (22.3\%) state ownership and highest (34.8\%) legal entity ownership of shares. Sub-industry 8 (medical and biological products) has the highest (40\%) public ownership while sub-industry 5 (electronic component and appliance) has the lowest (32.2\%). The average fraction of shares owned by employees is very small and ranges from $0.6 \%$ to $1.8 \%$ across sub-industries. In contrast, the average fraction of shares owned by the controlling shareholder is extremely large and ranges

12 There are more than 1100 firms listed on the two securities exchanges in China. Because productive efficiencies across different single-digit industries are hardly comparable, we only focus on the manufacturing industry, the largest industry amongst publicly listed firms. 
from $40 \%$ to $50 \%$, indicating a very high degree of ownership concentration. Regarding the identity of the controlling shareholder, state is the largest shareholder in about $35 \%$ of the firms in sub-industry 3 (representing the highest proportion) and 5\% of the firms in sub-industry 5 (representing the lowest proportion). In other sub-industries, state is the controlling shareholder in about $10 \%-20 \%$ of the firms. State-owned legal entity is the largest shareholder in the majority of firms (greater than 50\%). On average, board and supervisory committee structures do not vary much across sub-industries, and neither is provincial marketization index.

Table 3 illustrates the evolution of the output and inputs of the firms and their governance structure over time. As shown in the table, all the input and outputs in real terms have exhibited a steady rising trend but state and legal entity ownership of shares experience very little changes during the four-year sample period while public ownership of shares increases from $31.6 \%$ in 1999 to $37.2 \%$ in 2002 . The number of employee shares declines over time, due to the regulation issued by the CSRC to cease the issuance of employee shares in 1998. From 1999 to 2002 , the average proportion of shares held by the controlling shareholder decreases from $50 \%$ to 45.7\%. At the same time, the proportion of firms directly controlled by the state falls from $16.3 \%$ to $13.4 \%$ while the proportion of firms indirectly controlled by the state through ownership of legal entity shares increases from $59.5 \%$ to $65.9 \%$, suggesting that the government has downplayed its role as the direct controlling shareholder by transferring state shares to state-owned legal entities. The frequency of the dual role played by the general manager/CEO as board chair decreases from $27.3 \%$ to $13.8 \%$, representing a substantial decline in the power of general manager/CEO. ${ }^{13}$ The size of the board and the supervisory committee remain quite stable over time, while the average number of outside directors increases substantially from 0.03 to 2.24 , reflecting a move towards more outside-oriented board. On average, the number of board meetings per year increases from 4.6 to 8.5 , indicating that boards have become more active over time. In contrast, the average number of outside supervisors only increases a little, from 1.63 in 1999 to 1.84 in 2002.

13 The reduction of CEO duality is due to a piece of advice from the CSRC. Please refer to "Code of Corporate Governance in China's listed Firms" (CSRC, 2002) for more details. 


\section{Data envelopment analysis: Methodology and empirical results}

In this section, we apply a recently developed two-stage, bootstrapping data envelopment analysis (DEA) approach (Simar and Wilson, 2007) to examine the relationship between firm efficiency and corporate governance. Zheka (2005) summarizes the three advantages of applying DEA to corporate governance context. First, the DEA is a nonparametric approach and does not impose any specific assumption of production functional form. Second, DEA focuses on the individual observations rather than on population average, compared with the regression analysis. Third, it compares firm performance to the revealed best-practice frontier, rather than on the central-tendency properties of the frontier. ${ }^{14}$ Furthermore, Simar and Wilson (2007) show that their two-stage bootstrapping DEA is a valid procedure to correct the estimation bias and to deal with the serial-correlation problem in the previous literature. Therefore, the two-stage DEA approach is employed in this study.

\subsection{The DEA methodology}

The DEA methodology computes an efficiency score for a firm as the fraction of actual inputs that is required for the firm to be located on the efficient frontier to produce the same level of output. $^{15}$ Suppose there are $m$ inputs and $s$ outputs. Let the input and output data for decision-making unit $j$ be $x_{1, j}, x_{2, j}, \cdots, x_{m, j}$ and $y_{1, j}, y_{2, j}, \cdots, y_{s, j}$, respectively. The variable return to scale DEA model can be expressed with a real variable $\theta$ (efficiency score) and a non-negative vector of variables $\lambda=\begin{array}{lllll}\boldsymbol{Q}_{1} & \lambda_{2} & \cdots & \lambda_{n}{ }_{2}\end{array}$ as follows (Banker et al. 1984):

$$
\begin{array}{ll} 
& \theta^{*}=\min _{\lambda} \theta \\
\text { s.t } & \sum_{j=1}^{n} \lambda_{j} x_{i, j} \leq \theta x_{i, 0} ; \quad \sum_{j=1}^{n} \lambda_{j} y_{r, j} \geq y_{r, 0} ; \\
& \lambda_{j} \geq 0 ; \quad \sum \lambda_{\mathrm{j}}=1 ; \\
& i=1,2, \cdots, m ; \quad r=1,2, \cdots, s ; \quad j=1,2, \cdots, n
\end{array}
$$

Under the DEA method, a firm with an efficiency score of unity (100\%) is located on the

${ }^{14}$ Similar to Zheka (2005), an input-oriented DEA approach is adopted in our paper because of the excessive production inputs (e.g. excessive staffs) in many transitional economies and in China. However, we have also tried the output-oriented DEA approach. The results are qualitatively similar to that of the input-oriented one and the details are available upon request.

15 The DEA methodology has been widely used in economics and finance. See Cooper et al. (2000; 2004) for reviews of basic models, theoretical extensions and recent development. 
efficient frontier in the sense that its inputs cannot be further reduced without decreasing its output. A firm with an efficiency score below $100 \%$ is relatively inefficient.

To investigate the relationship between corporate governance mechanisms and firm efficiency, we follow a two-stage procedure common in the literature. During the first stage, we use three inputs (labor, capital stock and intermediate input) and one output (sales revenue in a given year) to estimate efficiency scores for each firm in the sample based on model (1). ${ }^{16}$ During the second stage, we use efficiency score as dependent variable and corporate governance proxies as independent variables and estimate the following equation:

$$
\begin{aligned}
e_{i, t}= & \alpha+\sum_{k} \beta_{k} X_{k, i, t}+\eta_{1} \text { FIRMAGE }_{i, t}+\eta_{2} \text { FIRMAGE }_{i, t}+\sum_{k} \phi_{k} \text { TIMEDUMMY } \\
& +\sum_{m} \theta_{m} I N D U S T R Y D U M M Y+\sum_{n} \lambda_{n} \text { PROVINCEDUMMY }+u_{i, t}
\end{aligned}
$$

where $e_{i, t}$ is the efficiency score for firm $i$ in year $t . X_{k, i, t}$ represents corporate governance variables discussed in Section 3. Firm age, squared firm age, and year, province and two-digit sub-industry dummies are included as control variables. ${ }^{17}$ Since efficiency scores are truncated below from zero and above from unity, $u_{i, t}$ is an error term with double-truncation. A common practice in the DEA-literature is to estimate equation (2) with a Tobit model. However, Simar and Wilson (2007) demonstrate that Tobit models are invalid due to complicated, unknown serial correlation among efficiency estimates. They propose an alternative two-stage, bootstrap truncated regression that is bias-corrected and heteroskedasticity-consistent. In this paper, we apply their two-stage estimation procedure, in particular their 'Algorithm 2' (Simar and Wilson, 2007, p.42-43), to investigate the main issues discussed in the previous section. In the first stage, efficiency scores $\hat{e}_{i, t}$ are obtained visa the biased-corrected estimation based on a consistent

${ }^{16}$ Ideally, output should be measured in physical units. Since our sample includes different sub-industries, using physical units will make it difficult to compare firm outputs across sub-industries. Hence, following previous studies (e.g., Zhang et al., 2001, Zheka, 2005), we measure output using the natural $\log$ of sales revenue. Labor and capital stock are computed using the number of employees and year-start net fixed assets, respectively. Intermediate input includes raw materials, energy and other productive goods. Variables measured in currency units are all deflated into real terms using the CPI index. All the inputs and output data are obtained from CSMAR database.

${ }^{17}$ Many SOEs in China carve out their most profitable assets and businesses into a joint stock company for the IPO in order to raise capital in the stock market (Zhang, 2004). Therefore, we use the number of years after going public (FIRMAGE) as a proxy for the actual age of the listed firms. 
bootstrapping DEA method for model (1). Then in the second stage, a truncated regression is applied to equation (2) to obtain coefficient estimates and the estimated variance of the residual. The significance level ( $p$-value) of these parameters are determined by a separate bootstrapping procedure that takes account of the double-truncation nature of the residual $u_{i, t}$. Zelenyuk and Zheka (2006) successfully applied this two-stage bootstrapping approach to study corporate governance and firm efficiency in Ukraine. ${ }^{18}$.

\subsection{The effects of corporate governance on firm efficiency}

Table 4 presents summary statistics for efficiency scores across time and 9 sub-industries. It is estimated based on an approach developed by Simar and Zelenyuk (2007). The group efficiency scores of each industry in each year are obtained from biased-corrected bootstrapping estimation based on group-wise heterogeneous sub-sampling procedure. The bootstrapped weighted mean, median, and standard deviation of efficiency scores, and 95\% confidence interval are all presented in the table. The weights of group aggregation are the observed revenue shares, which is based on the theory developed by Färe and Zelenyuk (2003).

As shown in Table 4, the weighted-mean and the median are very close. On average, the group-efficiency scores for sub-industries 5 (electronic component and appliance) and 8 (medicine and biological products) are over 0.75 , which are greater than those of other sub-industries. However, the group-efficiency scores do not vary substantially across sub-industries, given the fact that the $95 \%$ confidence intervals of the weighted-mean overlap with each other across sub-industries. That is different to the findings in other studies on transitional economies such as Ukraine (Zelenyuk and Zheka, 2006), where it was shown that the confidence intervals of different sub-industries were very wide and did not overlap. The average efficiency scores for sub-industries 4 (petroleum, chemical and plastics), 5 and 8 do not vary much over time. In contrast, the median group-efficiency score increases steadily from 0.595 in

18 We also tried the tobit regressions in the second stage estimation. The empirical results of the tobit models are qualitatively similar to those of the Simar-Wilson method. It suggests that although the S-W method may correct for some biases in the tobit method, the results in our case are not sensitive to these biases. 
1999 to 0.673 in 2002 for sub-industry 2 (textile, apparel, fur and leather) while it decreases gradually from 0.7 in 1999 to 0.681 in 2002 for sub-industry 1 (food and beverage).

Tables 5 contains empirical results of the second stage regressions of efficiency scores on corporate governance proxies. In particular, table 5 reports coefficient estimates and the associated bootstrapped, heteroskedasticity-consistent $p$-value from the truncated regression.

As shown in Table 5, most of the coefficient estimates from the truncated regressions are consistent to our hypotheses, firm efficiency is negatively related to state ownership and positively related to both public and employee ownerships, as the coefficient estimates on STATE, PUBLIC and EMPLOYEE are all statistically significant and of the expected signs. In particular, a $10 \%$ increase in state shares will decrease firm efficiency by about $0.8 \%$ after controlling for other variables and a $10 \%$ increase in public and employee shares will increase firm efficiency by about $0.6 \%$ and $3.8 \%$, respectively. The differential impact of public and employee shares shows that public ownership plays limited role in improving firm efficiency, perhaps due to the fact that public shares are widely dispersed among small investors. On the other hand, employee share ownership strengthens internal incentives for better performance, and hence is quite effective in raising firm efficiency.

The relationship between ownership concentration and firm efficiency is found to be U-shaped, as the coefficient estimates for LARGEST are significantly negative and the coefficient estimates for LARGEST2 are significantly positive, all at the 5\% level. This finding is consistent with our hypothesis. However, in the absence of direct evidence on related party transactions (RPTs) and earnings management, we can only note the pattern in the data without attributing the pattern to tunneling ${ }^{19}$ The identity of the controlling shareholder also affects firm efficiency in a substantial way. Among three types of controlling shareholders, state is the least efficient of all, followed by state-owned legal entities. Firms with state and state-owned legal entity as controlling shareholders are 5\% and $3.3 \%$ less efficient than those with other types of legal entities as controlling shareholders, respectively, as the coefficient estimates for STATECTRL and

${ }^{19}$ In a recent study, Jian and Wong (2004) find that group-controlled firms report abnormally high levels of related party sales when firms manipulate earnings to obtain permission to issue new equity or avoid being de-listed due to poor performance. 
LEGALSTACTRL are all significantly negative at the $1 \%$ level. Alternatively, firms identified with state as the ultimate controlling shareholder are approximately $6 \%$ less efficient than those with other types of shareholder as ultimate owners, as the coefficient estimates for ULTIMATE are significantly negative at the $1 \%$ level, indicating that political influences and government administrative interferences dramatically reduce firm efficiency. ${ }^{20}$

In addition, the coefficient estimates for the proportion of outside directors in the total number of the board of directors (OUTDRATIO) are all significantly positive at the 5\% level, suggesting that more outside oriented board is more effective. In particular, the efficiency gains for $10 \%$ increase in the outside directors in the board are approximately $1.1 \%$. Moreover, the coefficient estimates for BOARDMEETING are significantly positive at the $10 \%$ level in all of three truncated regressions, albeit with a small effect. It provides limited evidence that firms with more active boards are more efficient. An additional board meeting per year is associated with an increase in firm efficiency of $0.03 \%$, which is a very modest effect. In contrast, the coefficient estimates for DUALITY is not statistically significant, indicating that the dual role of general manager/CEO as board chair does not affect firm efficiency. The supervisory committee does not affect firm efficiency either, as the coefficient estimates for OUTSUPERVISOR are all statistically insignificant. This supports our prior analysis that the supervisory committee is more decorative than functional. In other words, among various types of internal corporate governance mechanisms, board of directors and supervisory committee only have limited roles in mitigating agency problem while ownership structure and ownership concentration play dominant roles in determining firm efficiency. ${ }^{21}$

Regarding the external corporate governance mechanism, the strength of provincial marketization and economic freedom is positively related to firm efficiency as the coefficient

${ }^{20}$ For example, the government may use the listed firms for personal gains or political nepotism. As many senior managers are appointed by the controlling shareholders for their political loyalty and seniority in the political system, they no doubt have little incentives in improving firm performance.

21 There could be interactions between ownership structure and board characteristics. For example, independent directors in government controlled firms may be less effective than the ones in non-government controlled firms. Therefore, we add interaction terms between STATE (and STATECTRL) and OUTDIRECTOR in all our regressions. The coefficients of the two interactive terms turn out to be negative but not statistically significant. For brevity of the paper, these results are not reported but available upon request. 
estimates for MARKETIZATION are all significantly positive. A one unit increase in the index leads to an average efficiency gain of more than $1.1 \%$, after controlling for the province in which a firm is located.

Table 5 also reveals that the relationship between productive efficiency and firm age is U-shaped. An explanation is that firms do not perform well after going public, in part because they only view stock market as a cheap place to raise capital and do not care about the interest of public investors. However, as time goes by, poor performing firms experience more difficulty in raising additional capital, so they strive to improve productive efficiency.

Finally, there is an economy-of-scale effect captured by the variable LOGASSET, which is positively significant at the $1 \%$ level. A $10 \%$ increase of the firm size in terms of fixed-asset will increase the efficiency by about $2.5 \%$.

\section{Conclusion and policy implications}

The literature on the corporate governance of transition economies leaves an open debate on whether or not ownership changes are necessary for improving the efficiency of SOEs. One side of the literature argues that because governments cannot play an active role in corporate governance, privatization with ownership changes is necessary for any significant performance improvements of SOEs. Another side argues that less radical methods such as managerial incentive contracts, market deregulation, and internal and external governance reform can be effective substitutes to outright privatization. To provide new empirical evidence and shed more light on the above important debate, this paper investigates whether and to what extent corporate governance mechanisms affect productive efficiency in a sample of 461 publicly listed manufacturing firms in China between 1999 and 2002.

In contrast to previous empirical work, we strive to capture corporate governance system more completely by simultaneously considering a unique set of governance practices inherent in the reform of SOEs in China, and by including a proxy for the strength of provincial market development to account for the effects of market liberalization on external governance and firm 
performance. $^{22}$ We also set up two-stage, bootstrapping data envelope analysis (DEA) approach (Simar and Wilson, 2007) to correct the potential estimation biases in the traditional Tobit and OLS models.

We find that our results are robust to the choice of empirical models and estimation techniques. Firm efficiency is negatively related to state ownership while positively related to public and employee share ownership. In addition, the relationship between ownership concentration and firm efficiency is U-shaped. Firms with government as ultimate owner or direct controlling shareholder are the least efficient. Board independence affect firm efficiency while other internal governance mechanisms have no significant impact. Moreover, external governance mechanism, as proxied by the NERI provincial marketization index, is positively related to productive efficiency. Overall, our findings show that restructuring SOEs via corporate governance reform has improved firm efficiency, but partial privatization without transfer of ownership and control to the public has remained a major source of inefficiency.

Our empirical results contain the following policy implications for the on-going corporate governance reform in China. First, ownership structure plays a dominant role in determining firm efficiency. As a result, the government should try to reduce state shares more aggressively and expand public and employee ownership more rapidly. Because the magnitude of efficiency gain is the largest when the proportion of employee shares rises, encouraging a viable long-term employee stock ownership program may significantly enhance performance incentives and improve firm efficiency. Second, firm efficiency is greatly reduced when state serves as the ultimate owner or controlling shareholder, in part due to a combination of tunneling activities and government interferences. Hence, decentralization via introducing more non-government institutional investors (such as mutual fund ownership) can be a useful way to balance the power

${ }^{22}$ By using the efficiency measure, we also alleviate the potential endogeneity problem caused by the omitted variable bias and the signal effect. Black et al. (2006) point out that firms may opt for good governance mechanisms to signal that insiders will be well-behaved. It is the signal, not a firm's governance practice, that affects share prices. In our case, it is less likely that a firm's signal to the stock market may influence its technical efficiency. However, it is still possible that more efficient firms tend to adopt better governance schemes. Lacking relevant developed technique in the DEA framework makes it difficult to address such issues in our paper. 
of control. $^{23}$ Another way is to transfer state shares to investment companies which function more like profit-maximizing businesses than administrative branches of the government. Third, it is widely documented that corporate boards play a critical role in limiting the power of controlling shareholders and protecting the interest of minority shareholders. Our results also indicate that board independence is positively related to firm efficiency. Therefore, it is very important that a stringent set of rules be put in place to ensure that directors are committed to good corporate governance practices. Fourth, the specific duties and rights of the supervisory committee are unclear under the current Company Law, therefore the committee is largely decorative than functional and plays no role in improving firm efficiency. It will be desirable to give supervisors more power to oversee business operations and financial conditions. It will be even better to allow supervisors to individually exercise their power without having to take actions collectively. For instance, a supervisor can require managers or directors to address a question or concern with respect to the business conditions and can file a complaint against them for any serious wrongdoing. Last but not the least, the government should deepen its market-oriented institutional reform by reducing political interference, fostering competition, encouraging regional mobility in factors of production and improving the legal environment, thereby establish a sound external corporate governance mechanism in synchronization with long-term development of a well-functioning capital market.

${ }^{23}$ In 2000, the CSRC issued a directive to encourage mutual funds to invest in tradable A-shares of listed companies and become active institutional investors to monitor managers and counter opportunistic behaviors. Since then, the growth of the mutual fund industry has been phenomenal. Specifically, the number of fund management companies increased from 6 in year 1998 to 57 in year 2006. The number of mutual funds (closed-end and open-end) increased from 5 in 1998 to 323 in 2006 . The net asset value of the mutual fund industry has increased from 10.74 billion Yuan in 1998 to 818.48 billion Yuan in 2006. The mean mutual fund ownership in our sample firms represents about $14 \%$ of the total number of tradable A-shares as of the end of 2005 (source: www.jrj.com.cn). 


\section{References}

Aivazian, V., Ge, Y., Qiu, J., 2005. Corporate governance and manager turnover: An unusual social experiment. Journal of Banking and Finance 29, 1459-1481.

Allen, F., Gale, D., 2000. Corporate governance and competition. In: Vives, X. (Ed.), Corporate Governance: Theoretical and Empirical Perspectives, pp.23-90. Cambridge University Press, Cambridge, U.K..

Allen, F., Qian, J., Qian, M., 2005. Law, finance, and economic growth in China. Journal of Financial Economics 77, 57-116.

Banker, R.D., Charnes, A., Cooper, W.W., 1984. Some models for estimation technical and scale inefficiencies in data envelopment analysis. Management Science 30, 1078-1109.

Black, B., Jang, H., Kim, W., 2006. Does corporate governance predicts firm's market value? Evidence from Korea. Journal of Law, Economics \& Organization 22, 366-413.

Boubakri, N., Cosset, J.C., Guedhami, O., 2005. Postprivatization corporate governance: the role of ownership structure and investor protection. Journal of Financial Economics 76, 369-399.

Boycko, M., Shleifer, A., Vishny, R., 1996. A theory of privatization. Economic Journal 106, 309-319.

Chen, G., Firth, M., Gao, D., Rui, O., 2006. Ownership structure, corporate governance, and fraud: Evidence from China. Journal of Corporate Finance 12, 424-448.

Chen, G., Firth, M., Rui, O., 2006. Have China's enterprise reforms led to improved efficiency and profitability. Emerging Markets Review 7, 82-109.

Cooper, W.W., Seiford, L.M., Tone, K., 2000. Data envelopment analysis: A comprehensive text with models, applications, references and DEA-solver. Kluwer Academic Publishers, Boston.

Cooper, W.W., Seiford, L.M., Zhu, J., 2004. Handbook on data envelopment analysis. Kluwer Academic Publishers, Boston.

CSRC, 2002. Code of Corporate Governance in China's listed Firms, www.csrc.gov.cn.

Dalton, D., Kesner, I., 1997. Composition and CEO duality in boards of directors: An international perspective. Journal of International Business Studies 18, 33-42.

Denis, D.K., McConnell, J., 2003. International corporate governance. Journal of Financial and Quantitative Analysis 38, 1-36. 
Djankov, S., Murrell, P., 2002. Enterprise restructuring in transition: a quantitative survey. Journal of Economics Literature 40, 739-792.

Dnes, A.W., 2005. Corporate governance: an international perspectives. Managerial and Decision Economics 26, 411-412.

Estrin, S., 2002. Competition and corporate governance in transition. Journal of Economic Perspectives 16, 101-124.

Fama, E., Jensen, M.C., 1983. Separation of ownership and control. Journal of Law and Economics 26, 301-325.

Fan, G., Wang, X.L., 2004. NERI Index of marketization of China's provinces. Economics Science Press (Chinese).

Färe, R., Zelenyuk, V., 2003. On aggregate Farrell efficiencies. European Journal of Operation Research 146, 615-621.

Firth, M., Fung, P. M. Y., Rui, O. M., 2006a. Corporate performance and CEO compensation in China. Journal of Corporate Finance 12, 693-714.

Firth, M., Fung, P. M. Y., Rui, O. M., 2006b. Firm performance, governance structure, and top management turnover in a transitional economy. Journal of Management Studies 43, 1289-1330.

Himmelberg, C.P., Hubbard, R.G., Parlia, D., 1999. Understanding the determinants of managerial ownership and link between ownership and performance. Journal of Financial Economics 53, 353-384.

Huson, M.R., Parrino, R., Starks, L.T., 2001. Internal monitoring mechanisms and CEO turnover: A long-term perspective. Journal of Finance 56, 2265-2297.

Jian, M. and Wong, T. J., 2004. Earnings Management and Tunneling through Related Party Transactions: Evidence from Chinese Corporate Groups. Working paper, Chinese University of Hong Kong.

Johnson, S., La Porta, R., Lopez-de-Silanes, F., Shleifer, A., 2000. Tunneling. American Economic Review 90, 22-27.

Kornai, J., 1986. The soft budget constraints. Kyklos 39, 3-30.

La Porta, R., Loped-de-Silanes., F., Shleifer, A., Vishny, R., 1999. Corporate ownership around 
the world. Journal of Finance 54, 471-517

La Porta, R., Lopez-de-Silanes, F., Shleifer, A., Vishny, R., 2000 "Investor protection and corporate governance” Journal of Financial Economics 58, 141-186

Lin, J., Cai, F., Li, Z., 1998. Competition, policy burdens, and state-owned enterprise reform. American Economic Review 88, 422-427.

Liu, G., Sun, P., 2003. Identifying ultimate controlling shareholders in Chinese public corporation: an empirical survey. Royal Institute of International Affairs Working Paper.

Liu, S., 2005. Corporate governance and development: the case of China. Managerial and Decision Economics 26, 445-449.

Megginson, W., Netter, J.N., 2001. From state to market: a survey of empirical studies on privatization. Journal of Economics Literature 39, 321-389.

Megginson, W., 2005. The financial economics of privatization. Oxford University Press.

Morck, R., Yueng, B., Yu, W., 2000. The information content of stock market: why do emerging markets have synchronous stock price movement? Journal of Financial Economics 58, 215-20.

Qian, Y., 1996. Enterprise reform in China: Agency problems and political control. Economics of Transition 4, 427-447.

Shleifer, A., 1998. State versus private ownership. Journal of Economic Perspectives 12, $133-150$.

Shleifer, A., Vishny, R., 1994. Politicians and firms. Quarterly Journal of Economics 109, 995-1025.

Shleifer, A., Vishny, R., 1997. A survey of corporate governance. Journal of Finance 52, 737-777.

Shirley, M., Patrick, W., 2000. Public vs. private ownership: the current state of the debate. World Bank Working Paper.

Simar, L., Wilson, P., 2007. Estimation and inference in two-stage, semi-parametric models of production processes. Journal of Econometrics 136, 31-64.

Simar, L., Zelenyuk, V., 2007. Statistical inference for aggregates of Farrell-type efficiencies. Journal of Applied Econometrics, 22, 1367-1394.

Su, D., 2005. Corporate finance and state enterprise reform in China. China Economic Review 16, 
118-148.

Sun, Q., Tong, W., 2003. China share issue privatization: the extent of its success. Journal of Financial Economics 70, 183-222.

Vickers, J., Yarrow, G., 1991. Economic perspectives on privatization. Journal of Economic Perspectives 5, 111-132.

Wei, Z., Xie, F., Zhang, S., 2005. Ownership structure and firm value in China's privatized firms: 1991-2001. Journal of Financial and Quantitative Analysis 40, 87-108.

Zhang, A., Zhang, Y., Zhao, R., 2001. Impact of ownership and competition on the productivity of Chinese enterprises. Journal of Comparative Economics 29, 327-346.

Zhang, W.G., 2004. Shareholding structure, related party transaction and corporate governance: An in-depth analysis of the issues in China. China Securities Regulatory Commission.

Zheka, V., 2005. Corporate governance, ownership structure and corporate efficiency: the Case of Ukraine. Managerial and Decision Economics 26, 451-460.

Zelenyuk, V., Zheka, V., 2006. Corporate governance and firm's efficiency: the case of a transitional country, Ukraine. Journal of Productivity Analysis 25, 143-157. 
Table 1: Classification of the nine sub-industries

\begin{tabular}{clrrr}
\hline Sub-industry & & Frequency & Percentage & $\begin{array}{c}\text { Cumulative } \\
\text { percentage }\end{array}$ \\
& & & & \\
1 & Food and beverages & 146 & 8.86 & 8.86 \\
2 & Textile, apparel, fur and leather & 129 & 7.83 & 16.69 \\
3 & Paper and allied products & 58 & 3.52 & 20.21 \\
4 & Petroleum, chemical and plastics & 318 & 19.30 & 39.50 \\
5 & Electronic component and appliance & 92 & 5.58 & 45.08 \\
6 & Metal, mineral and cement & 268 & 16.26 & 61.35 \\
7 & Machinery, equipment and instrument & 466 & 28.28 & 89.62 \\
8 & Medicine and biological products & 141 & 8.56 & 98.18 \\
9 & Others & 30 & 1.82 & 100 \\
\hline Total & & 1648 & 100 & \\
\hline
\end{tabular}


Table 2: Summary statistics by sub-industries

\begin{tabular}{|c|c|c|c|c|c|c|c|c|c|c|}
\hline \multirow{2}{*}{\multicolumn{11}{|c|}{ A. Output and inputs of firms }} \\
\hline & & & & & & & & & & \\
\hline \multirow{2}{*}{$\begin{array}{l}\text { REVENUE } \\
\text { (mil. yuan) }\end{array}$} & Mean & 930 & 752 & 429 & 989 & 1,832 & 1,580 & 1,041 & 718 & 442 \\
\hline & Std dev & 956 & 795 & 317 & 1,702 & 2,379 & 2,433 & 1,455 & 1,016 & 438 \\
\hline \multirow{2}{*}{$\begin{array}{l}\text { EMPLOYEE } \\
(' 000)\end{array}$} & Mean & 3 & 4 & 2 & 3 & 4 & 5 & 3 & 3 & 1 \\
\hline & Std dev & 3 & 3 & 1 & 3 & 5 & 7 & 3 & 3 & 1 \\
\hline \multirow{4}{*}{$\begin{array}{l}\text { KSTOCK } \\
\text { (mil. yuan) } \\
\text { INTERM } \\
\text { (mil. yuan) }\end{array}$} & Mean & 493 & 420 & 383 & 1,073 & 818 & 1,398 & 521 & 376 & 305 \\
\hline & Std dev & 438 & 322 & 304 & 2,202 & 837 & 2,337 & 547 & 459 & 208 \\
\hline & Mean & 686 & 639 & 349 & 891 & 1,574 & 1,297 & 860 & 501 & 379 \\
\hline & Std dev & 714 & 704 & 282 & 1,750 & 2,209 & 2,291 & 1,245 & 834 & 393 \\
\hline \multicolumn{11}{|c|}{ B. Corporate governance indicators } \\
\hline \multirow[t]{2}{*}{ STATE } & Mean & 0.374 & 0.272 & 0.430 & 0.334 & 0.303 & 0.387 & 0.342 & 0.287 & 0.223 \\
\hline & Std dev & 0.270 & 0.253 & 0.216 & 0.270 & 0.267 & 0.296 & 0.269 & 0.243 & 0.235 \\
\hline \multirow[t]{2}{*}{$L E G A L$} & Mean & 0.242 & 0.287 & 0.168 & 0.269 & 0.293 & 0.211 & 0.244 & 0.272 & 0.348 \\
\hline & Std dev & 0.252 & 0.245 & 0.173 & 0.268 & 0.245 & 0.236 & 0.259 & 0.262 & 0.254 \\
\hline \multirow[t]{2}{*}{$P U B L I C$} & Mean & 0.346 & 0.366 & 0.359 & 0.359 & 0.322 & 0.323 & 0.341 & 0.400 & 0.345 \\
\hline & Std dev & 0.112 & 0.112 & 0.114 & 0.123 & 0.113 & 0.112 & 0.132 & 0.129 & 0.099 \\
\hline \multirow[t]{2}{*}{ EMPLOYEE } & Mean & 0.006 & 0.013 & 0.018 & 0.006 & 0.004 & 0.011 & 0.009 & 0.007 & 0.008 \\
\hline & Std dev & 0.023 & 0.044 & 0.056 & 0.029 & 0.023 & 0.042 & 0.040 & 0.032 & 0.027 \\
\hline \multirow[t]{2}{*}{ LARGEST } & Mean & 0.507 & 0.398 & 0.472 & 0.492 & 0.474 & 0.504 & 0.484 & 0.430 & 0.432 \\
\hline & Std dev & 0.166 & 0.145 & 0.153 & 0.180 & 0.164 & 0.187 & 0.159 & 0.170 & 0.165 \\
\hline \multirow[t]{2}{*}{ STATECTRL } & Mean & 0.237 & 0.190 & 0.348 & 0.111 & 0.053 & 0.162 & 0.115 & 0.173 & 0.100 \\
\hline & Std dev & 0.427 & 0.394 & 0.480 & 0.314 & 0.226 & 0.369 & 0.320 & 0.379 & 0.304 \\
\hline \multirow[t]{2}{*}{ LEGALSTACTRL } & Mean & 0.572 & 0.389 & 0.576 & 0.717 & 0.649 & 0.615 & 0.719 & 0.543 & 0.725 \\
\hline & Std dev & 0.496 & 0.489 & 0.498 & 0.451 & 0.480 & 0.487 & 0.450 & 0.500 & 0.452 \\
\hline \multirow[t]{2}{*}{ ULTIMATE } & Mean & 0.852 & 0.707 & 0.894 & 0.904 & 0.901 & 0.820 & 0.872 & 0.764 & 0.735 \\
\hline & Std dev & 0.357 & 0.457 & 0.310 & 0.295 & 0.300 & 0.3 & 0.3 & 0.426 & 0.448 \\
\hline \multirow[t]{2}{*}{ DUALITY } & Mean & 0.232 & 0.257 & 0.118 & 0.242 & 0.163 & 0.174 & 0.136 & 0.226 & 0.275 \\
\hline & Std dev & 0.423 & 0.438 & 0.325 & 0.429 & 0.372 & 0.380 & 0.343 & 0.419 & 0.452 \\
\hline \multirow[t]{2}{*}{ BOARDMEETING } & Mean & 6.299 & 6.034 & 6.574 & 6.112 & 6.481 & 5.951 & 6.258 & 6.031 & 6.275 \\
\hline & Std dev & 2.680 & 2.915 & 3.542 & 2.923 & 3.402 & 2.624 & 2.773 & 2.879 & 3.530 \\
\hline \multirow[t]{2}{*}{ OUTDRATIO } & Mean & 0.073 & 0.094 & 0.072 & 0.073 & 0.075 & 0.075 & 0.075 & 0.081 & 0.066 \\
\hline & Std dev & 0.115 & 0.132 & 0.123 & 0.116 & 0.125 & 0.112 & 0.117 & 0.130 & 0.115 \\
\hline \multirow[t]{2}{*}{ OUTSUPERRATIO } & Mean & 0.305 & 0.440 & 0.441 & 0.418 & 0.400 & 0.394 & 0.411 & 0.345 & 0.424 \\
\hline & Std dev & 0.317 & 0.321 & 0.312 & 0.318 & 0.266 & 0.294 & 0.291 & 0.260 & 0.331 \\
\hline \multirow[t]{2}{*}{ FIRM AGE } & Mean & 4.910 & 5.443 & 4.742 & 5.359 & 5.842 & 5.377 & 5.680 & 5.694 & 5.059 \\
\hline & Std dev & 2.099 & 2.379 & 1.956 & 2.064 & 2.489 & 2.163 & 2.258 & 2.180 & 2.570 \\
\hline \multirow[t]{2}{*}{ LOGASSET } & Mean & 11.748 & 11.510 & 11.556 & 11.721 & 12.218 & 11.896 & 11.674 & 11.635 & 11.689 \\
\hline & Std dev & 0.644 & 0.751 & 0.603 & 0.763 & 0.938 & 0.951 & 0.874 & 0.730 & 0.707 \\
\hline \multirow[t]{2}{*}{ MARKETIZATION } & Mean & 5.780 & 6.883 & 5.659 & 5.935 & 7.200 & 5.825 & 6.300 & 6.261 & 6.728 \\
\hline & Std dev & 1.498 & 1.571 & 1.316 & 1.479 & 1.772 & 1.617 & 1.539 & 1.493 & 1.396 \\
\hline
\end{tabular}


Table 3: Summary statistics by year

\begin{tabular}{|c|c|c|c|c|c|}
\hline & & 1999 & 2000 & 2001 & 2002 \\
\hline \multicolumn{6}{|c|}{ A. Output and inputs of firms } \\
\hline REVENUE & Mean & 864 & 1,012 & 1,101 & 1,279 \\
\hline (mil. yuan) & Std dev & 1,347 & 1,567 & 1,736 & 1,906 \\
\hline EMPLOYEE & Mean & 34 & 34 & 35 & 35 \\
\hline ('000) & Std dev & 39 & 38 & 42 & 40 \\
\hline KSTOCK & Mean & 626 & 726 & 785 & 867 \\
\hline (mil. yuan) & Std dev & 1,334 & 1,299 & 1,638 & 1,522 \\
\hline INTERM & Mean & 698 & 834 & 933 & 1,060 \\
\hline (mil. yuan) & Std dev & 1,263 & 1,432 & 1,654 & 1,742 \\
\hline \multicolumn{6}{|c|}{ B. Corporate governance indicators } \\
\hline \multirow[t]{2}{*}{ STATE } & Mean & 0.350 & 0.356 & 0.323 & 0.322 \\
\hline & Std dev & 0.281 & 0.267 & 0.268 & 0.264 \\
\hline \multirow[t]{2}{*}{$L E G A L$} & Mean & 0.257 & 0.238 & 0.258 & 0.255 \\
\hline & Std d & 0.260 & 0.250 & 0.253 & 0.252 \\
\hline \multirow[t]{2}{*}{ PUBLIC } & Mean & 0.316 & 0.345 & 0.362 & 0.372 \\
\hline & Std dev & 0.111 & 0.121 & 0.125 & 0.127 \\
\hline \multirow[t]{2}{*}{ EMPLOYEE } & Mean & 0.019 & 0.010 & 0.005 & 0.001 \\
\hline & Std dev & 0.053 & 0.040 & 0.027 & 0.010 \\
\hline \multirow[t]{2}{*}{ LARGEST } & Mean & 0.500 & 0.482 & 0.468 & 0.457 \\
\hline & & 0.171 & 0.171 & 0.169 & 0.171 \\
\hline \multirow[t]{2}{*}{ STATECTRL } & Mean & 0.163 & 0.151 & 0.148 & 0.134 \\
\hline & Std dev & 0.370 & 0.359 & 0.355 & 0.341 \\
\hline \multirow[t]{2}{*}{ LEGALSTACTRL } & Mean & 0.595 & 0.643 & 0.649 & 0.659 \\
\hline & Std dev & 0.491 & 0.480 & 0.478 & 0.474 \\
\hline \multirow[t]{2}{*}{ ULTIMATE } & Mean & 0.862 & 0.852 & 0.848 & 0.820 \\
\hline & Std $c$ & 0.34 & 0.3 & 0.3 & 0.384 \\
\hline \multirow[t]{2}{*}{ DUALITY } & Mean & 0.273 & 0.211 & 0.148 & 0.138 \\
\hline & Std dev & 0.446 & 0.408 & 0.356 & 0.345 \\
\hline \multirow[t]{2}{*}{ BOARDMEETING } & Mean & 4.612 & 5.400 & 6.138 & 8.512 \\
\hline & Std dev & 2.069 & 2.381 & 2.493 & 2.907 \\
\hline \multirow[t]{2}{*}{ OUTDRATIO } & Mean & 0.003 & 0.007 & 0.051 & 0.234 \\
\hline & Std dev & 0.026 & 0.039 & 0.102 & 0.085 \\
\hline \multirow[t]{2}{*}{ OUTSUPERRATIO } & Mean & 0.355 & 0.384 & 0.436 & 0.414 \\
\hline & Std dev & 0.306 & 0.308 & 0.291 & 0.296 \\
\hline \multirow[t]{2}{*}{ FIRM AGE } & Mean & 4.2 & 4.816 & 5.812 & 6.805 \\
\hline & Std dev & 1.840 & 2.034 & 2.027 & 2.031 \\
\hline \multirow[t]{2}{*}{ LOAGASSET } & Mean & 11.560 & 11.706 & 11.791 & 11.861 \\
\hline & Std dev & 0.825 & & & 0.852 \\
\hline \multirow[t]{2}{*}{ MARKETIZATION } & Mean & 5.713 & 5.941 & 6.396 & 6.677 \\
\hline & Std dev & 1.420 & 1.468 & 1.586 & 1.691 \\
\hline
\end{tabular}


Table 4: Summary statistics of group-efficiency scores across time and sub-industries

\begin{tabular}{|c|c|c|c|c|c|c|c|c|}
\hline & 1999 & 2000 & 2001 & 2002 & 1999 & 2000 & 2001 & 2002 \\
\hline \multicolumn{5}{|l|}{ 1. Food and beverage } & \multicolumn{4}{|c|}{ 2. Textile, apparel, fur and leather } \\
\hline $\begin{array}{l}\text { Weighted } \\
\text { group-efficiency }\end{array}$ & 0.700 & 0.673 & 0.677 & 0.684 & 0.599 & 0.598 & 0.669 & 0.662 \\
\hline Median & 0.700 & 0.679 & 0.678 & 0.681 & 0.595 & 0.599 & 0.673 & 0.673 \\
\hline Standard deviation & 0.060 & 0.078 & 0.062 & 0.081 & 0.075 & 0.060 & 0.066 & 0.072 \\
\hline $95 \%$ C.I. lower bound & 0.567 & 0.534 & 0.573 & 0.520 & 0.461 & 0.482 & 0.544 & 0.513 \\
\hline $95 \%$ C.I. upper bound & 0.792 & 0.786 & 0.798 & 0.836 & 0.722 & 0.713 & 0.791 & 0.782 \\
\hline \multicolumn{5}{|c|}{ 3. Paper and allied products } & \multicolumn{4}{|c|}{ 4. Petroleum, chemical and plastics } \\
\hline $\begin{array}{l}\text { Weighted } \\
\text { group-efficiency }\end{array}$ & 0.592 & 0.520 & 0.558 & 0.598 & 0.641 & 0.678 & 0.681 & 0.683 \\
\hline Median & 0.592 & 0.516 & 0.553 & 0.591 & 0.628 & 0.678 & 0.693 & 0.684 \\
\hline Standard deviation & 0.090 & 0.064 & 0.089 & 0.093 & 0.112 & 0.122 & 0.101 & 0.109 \\
\hline $95 \%$ C.I. lower bound & 0.432 & 0.418 & 0.419 & 0.444 & 0.446 & 0.496 & 0.493 & 0.489 \\
\hline $95 \%$ C.I. upper bound & 0.747 & 0.647 & 0.741 & 0.750 & 0.841 & 0.863 & 0.841 & 0.859 \\
\hline \multicolumn{5}{|c|}{ 5. Electronic component and appliance } & \multicolumn{4}{|c|}{ 6. Metal, mineral and cement } \\
\hline $\begin{array}{l}\text { Weighted } \\
\text { group-efficiency }\end{array}$ & 0.814 & 0.759 & 0.768 & 0.802 & 0.733 & 0.707 & 0.723 & 0.778 \\
\hline Median & 0.826 & 0.765 & 0.779 & 0.805 & 0.754 & 0.718 & 0.730 & 0.797 \\
\hline Standard deviation & 0.105 & 0.099 & 0.099 & 0.088 & 0.084 & 0.092 & 0.089 & 0.099 \\
\hline $95 \%$ C.I. lower bound & 0.591 & 0.582 & 0.597 & 0.631 & 0.544 & 0.530 & 0.538 & 0.565 \\
\hline $95 \%$ C.I. upper bound & 0.946 & 0.912 & 0.914 & 0.937 & 0.852 & 0.837 & 0.850 & 0.913 \\
\hline \multicolumn{5}{|c|}{ 7. Machinery, equipment and instrument } & \multicolumn{4}{|c|}{ 8. Medicine and biological products } \\
\hline $\begin{array}{l}\text { Weighted } \\
\text { group-efficiency }\end{array}$ & 0.685 & 0.686 & 0.700 & 0.760 & 0.721 & 0.765 & 0.749 & 0.809 \\
\hline Median & 0.694 & 0.689 & 0.712 & 0.761 & 0.713 & 0.766 & 0.759 & 0.817 \\
\hline Standard deviation & 0.085 & 0.086 & 0.082 & 0.058 & 0.101 & 0.086 & 0.087 & 0.075 \\
\hline $95 \%$ C.I. lower bound & 0.517 & 0.523 & 0.514 & 0.647 & 0.555 & 0.612 & 0.575 & 0.664 \\
\hline $95 \%$ C.I. upper bound & 0.815 & 0.832 & 0.824 & 0.861 & 0.898 & 0.912 & 0.905 & 0.926 \\
\hline \multicolumn{9}{|l|}{ 9. Others } \\
\hline $\begin{array}{l}\text { Weighted } \\
\text { group-efficiency }\end{array}$ & 0.680 & 0.742 & 0.684 & 0.704 & & & & \\
\hline Median & 0.681 & 0.756 & 0.677 & 0.690 & & & & \\
\hline Standard deviation & 0.103 & 0.091 & 0.094 & 0.119 & & & & \\
\hline $95 \%$ C.I. lower bound & 0.446 & 0.555 & 0.520 & 0.489 & & & & \\
\hline $95 \%$ C.I. upper bound & 0.859 & 0.899 & 0.837 & 0.917 & & & & \\
\hline
\end{tabular}

Note: Estimation is based on Simar and Zelenyuk (2007) group-wise heterogeneous

sub-sampling procedure, with 2,000 bootstrap replications both for bias-correction and for $95 \%$ confidence-interval (C. I.) estimation. Sub-sample size for each group in each year $l t(l=1,2, \ldots 9$; $t=1999,2000,2001,2002)$ is given as $m_{l t}=n_{l t}^{0.7}$. Weights are observed revenue of firms. 
Table 5: Two-stage bootstrapping DEA truncated regression estimates of the relationship between corporate governance and firm efficiency

\begin{tabular}{|c|c|c|c|c|c|c|}
\hline \multirow[b]{2}{*}{ Regressors } & \multicolumn{2}{|c|}{ Spec. 1} & \multicolumn{2}{|c|}{ Spec. 2} & \multicolumn{2}{|c|}{ Spec. 3} \\
\hline & Coefficient & p-value & Coefficient & $p$-value & Coefficient & $p$-value \\
\hline STATE & $-0.0825^{* * *}$ & 0.000 & & & & \\
\hline PUBLIC & $0.0627 * *$ & 0.045 & & & & \\
\hline EMPLOYEE & $0.3751 * * *$ & 0.002 & & & & \\
\hline$L A R G E S T$ & $-0.2274 * *$ & 0.022 & $-0.2298 * *$ & 0.042 & $-0.2226 * *$ & 0.034 \\
\hline LARGEST2 & $0.2055 * *$ & 0.046 & $0.1491 * *$ & 0.021 & $0.1609 * *$ & 0.016 \\
\hline STATECTRL & & & $-0.0503 * * *$ & 0.000 & & \\
\hline LEGALSTACTRL & & & $-0.0339 * * *$ & 0.000 & & \\
\hline ULTIMATE & & & & & $-0.0603 * * *$ & 0.000 \\
\hline OUTDRATIO & $0.1131 * *$ & 0.018 & $0.1112 * *$ & 0.014 & $0.1122 * * *$ & 0.008 \\
\hline BOARDMEETING & $0.0002 *$ & 0.085 & $0.0003 *$ & 0.083 & $0.0001 *$ & 0.097 \\
\hline DUALITY & 0.0236 & 0.412 & 0.0240 & 0.624 & 0.0221 & 0.562 \\
\hline MARKETIZATION & $0.0107 * *$ & 0.041 & $0.0125 * *$ & 0.036 & $0.0124 * *$ & 0.034 \\
\hline OUTSUPERRATIO & 0.0055 & 0.618 & 0.0083 & 0.470 & 0.0143 & 0.208 \\
\hline FIRMAGE & $-0.0202 * * *$ & 0.008 & $-0.0249 * * *$ & 0.000 & $-0.0266 * * *$ & 0.000 \\
\hline FIRMAGE2 & $0.0015 * *$ & 0.022 & $0.0017 * * *$ & 0.008 & $0.0019 * * *$ & 0.002 \\
\hline LOGASSET & $0.0339 * * *$ & 0.000 & $0.0335 * * *$ & 0.000 & $0.0315^{* * *}$ & 0.000 \\
\hline constant & $0.1248 * *$ & 0.033 & $0.1602 * *$ & 0.023 & $0.2163 * *$ & 0.012 \\
\hline$\sigma_{u}^{2}$ & $0.1265 * * *$ & 0.000 & $0.1269 * * *$ & 0.000 & $0.1274 * * *$ & 0.000 \\
\hline Log likelihood & 1077.1300 & & 1071.8860 & & 1064.9060 & \\
\hline
\end{tabular}

Notes: (1) Included observations are 1648 firm-year, over the period of 1999-2002. (2) Estimation is based on Algorithm 2 of Simar and Wilson (2007), with 2,000 bootstrap replications each for bias-correction and for p-value evaluation of the estimated coefficients. (3) The dependent variable is bootstrap-bias-corrected DEA efficiency score of firm $i$. STATE is the fraction of total outstanding shares held by local and central government, PUBLIC is the fraction of total outstanding shares held by the investment public, EMPLOYEE is the fraction of total outstanding shares held by workers and managers, LARGEST is the fraction of total outstanding shares held by the largest shareholder, LARGEST2 is the squared term for LARGEST, STATECTRL is a dummy variable that takes 1 if government is the largest shareholder and 0 otherwise, LEGALSTACTRL is a dummy variable that takes 1 if government-controlled legal entity is the largest shareholder and 0 otherwise, ULTIMATE is a dummy variable that takes 1 if government is the ultimate owner and 0 otherwise, OUTDRATIO is the ratio of outside directors in the board of directors, DUALITY is a dummy variable that takes 1 if general manager/CEO is also the board chair and 0 otherwise, BOARDMEETING is the number of board meetings per year, OUTSUPERRATIO is the ratio of outside supervisors, LOGASSET is the log of fixed-asset (a proxy for the firm size), FIRMAGE is the number of years after going public for a firm, FIRMAGE2 is the squared term for FIRMAGE, and MARKETIZATION is a proxy for the strengthen of provincial market development. Year, province and sub-industry dummies are omitted for brevity. (4) The bootstrapped $p$-values are in the parentheses. *,**, and *** indicates statistically significance at the $10 \%, 5 \%$ and $1 \%$ level, respectively. 